\title{
The sex ratio, Gonadosomatic Index and Fecundity of the Copper Mahaseer, Neolissochilus hexagonolepis (Mc Clelland, 1839) from Tamor river, Nepal
}

\author{
S. Subba ${ }^{1 *}$ and V.K. Mahaseth ${ }^{2}$ \\ ${ }^{I}$ Institute of Science and Technology, Dhankuta Multiple campus, T.U., Dhankuta, Nepal \\ ${ }^{2}$ Department of Zoology, M.M.A.M. Campus, T.U., Biratnagar, Nepal \\ *E-mail: surensubba35@yahoo.com
}

\begin{abstract}
The sex ratio, Gonado Somatic Index and fecundity of the Copper Mahseer, Neolissochilus hexagonolepis were investigated. The sex ratio was 1:1.2 (Male to female). The gonado-somatic index ranged from $0.084 \%$ to $16.47 \%$ for female fish and $0.086 \%$ to $5.81 \%$ for male fish. The highest mean GSI $9.037 \%$ was recorded in July for female fishes and the highest $2.838 \%$ was recorded in September for male fishes. The total weight and total length of the fishes had strong positive correlation. Also, the correlation between the weight of gonad and GSI was positively correlated. Absolute fecundity ranged from to 11424 . Fecundity had strong positive correlation with total length $(r=0.98)$, total weight $(\mathrm{r}=0.9)$ and total length $(\mathrm{r}=0.88)$.
\end{abstract}

Key words: Tamor river, Fecundity, Gonadosomatic index, Sex-ratio, Neolissochilus hexagonolepis

\section{Introduction}

Tamor river is a major river in eastern Nepal, which origins from Kanchenjunga. Tamor and Arun rivers join with Sunkoshi at Tribenighat to form the Saptakoshi which flows through Mahabharat Range upto the Gangetic plain. The total length of this river is about $190 \mathrm{~km}$ with $5817 \mathrm{~km}^{2}$ catchment area. This river is a good source for capture fisheries and forms the lifeline for the rural economy of this region. Tamor river is the home as well as the breeding ground for many species of fishes. In addition to this, this river acts as the passage for some of the interesting migratory fishes.

Neolissochilus hexagonolepis is commonly known as Copper Mahseer. In Nepal, the species is recorded from Gandaki, Trishuli, Karnali, Mahakali river basins (Shrestha 2003). According to IUCN list, this species is considered as near threatened (IUCN 2012). It inhabits streams with fast flowing water mostly in high gradient and low gradient riffles and pools (Menon 1999). It prefers rocky and boulder areas with high flow. It is an omnivorous fish and feeds mainly on filamentous green algae, lesser on chironomid larvae, crustaceans and water beetles (Ferro and Badagami 1980). This fish migrates upstream during the breeding season where spawning takes place on stones and gravel (Rai and Swar, 1989). This fish is commercially important species and is widely recognized as sport fish due to its tremendous size and strength (Marwein, 2000 ; Mahapatra et al., 2004). Tamor River serves as the suitable home ground and breeding ground for this fish.

Fecundity can be defined as the number of eggs in the ovary of a gravid fish and it can be used by the fisheries scientists in stock management, egg and larval survival studies, standing stock size estimate, exploited stock prediction, recruitment studies and formulation of management strategies. 


\section{Materials and Methods}

Study area

The study area for this research is Tamor River, which lies approximately between latitude and longitude coordinates of 26.916667 and 87.166667 respectively. Four sampling stations Yakchanaghat (N 26 56.700', E 087²3.097'), Ghumaune (N 2656.023', E 087¹9.908'),

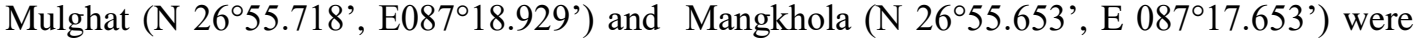
selected along the river length (Figure 1).

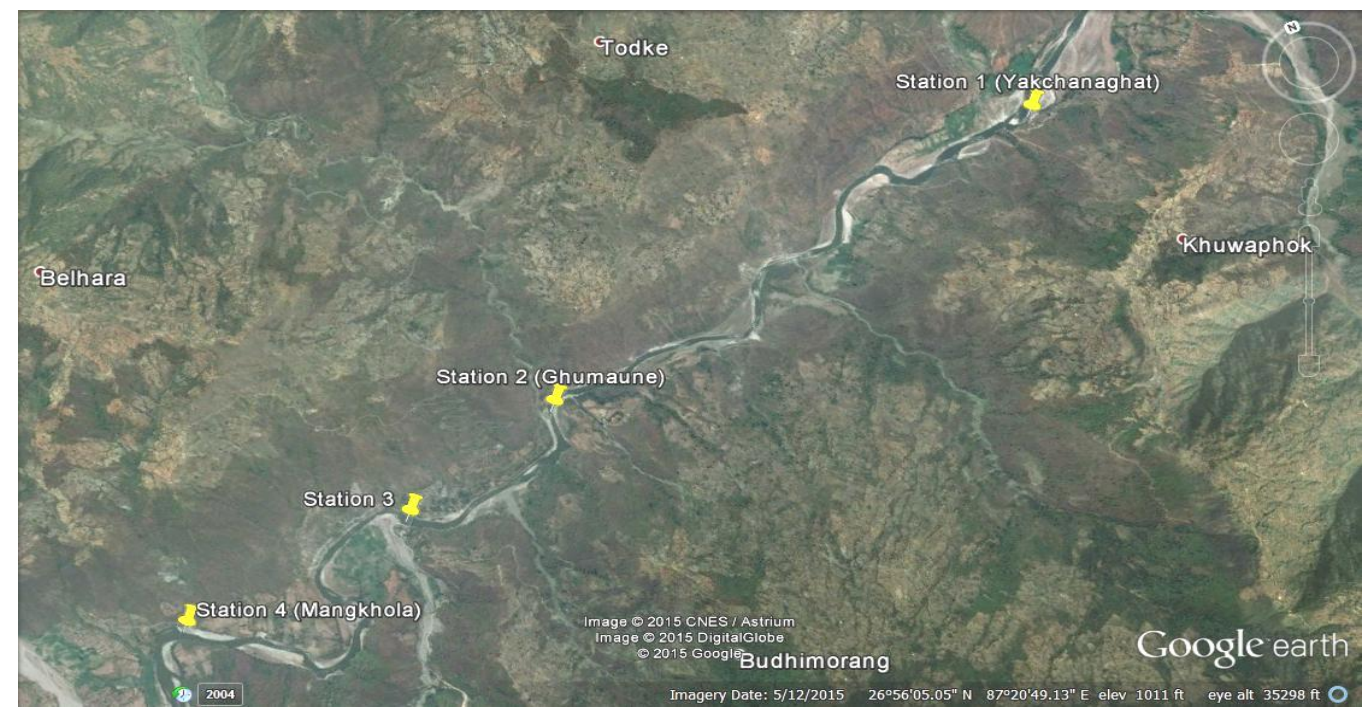

Figure 1. Part of the river showing sampling stations.

Fish sampling and identification of $N$. hexagonolepis and their sexes

Fishes were collected from catch landings of fishermen using fishing gears such as hooks, cast net, gill net and traps. The abdominal region of the fish was dissected out to determine the sex of the fish. Sexes of the fish was determined by visual and microscopic examination of the gonads. The sex ratio was calculated by using the proportion of the two sexes relative to one another.

\section{Study of Physico-chemical parameters of water}

Physico-chemical parameters such as atmospheric temperature, water temperature, dissolved oxygen (DO), $\mathrm{pH}$, free $\mathrm{CO}_{2}$, total alkalinity, total hardness were studied. Water samples were collected from all the four sampling stations on fortnightly basis and then analyzed. $\mathrm{pH}$ of water was measured at the site using systronic battery operated $\mathrm{pH}$ meter. Atmospheric and water temperatures were studied at the sites, with the help of simple mercury filled Celsius thermometer having the accuracy of $0.1{ }^{\circ} \mathrm{C}$ to $50{ }^{\circ} \mathrm{C}$.

Dissolved oxygen was fixed at the site and estimated in the laboratory by Winkler's method. In this method the oxygen first oxidizes manganous sulphate and liberates iodine from acidified potassium iodide. The iodine, equivalent to dissolved oxygen, is determined by titration against standard sodium thiosulphate.

Free carbon dioxide was determined titrimetrically using $\mathrm{N} / 44 \mathrm{NaOH}$, using Phenolphthalein as an indicator. Total alkalinity was measured by titrating against $0.01 \mathrm{~N} \mathrm{HCl}$, using Phenolphthalein and Methyl orange as indicators. 
Total hardness of water was estimated by EDTA method. In this method Eriochrome black T forms wine-red complex compound with metal ions $(\mathrm{Ca}++$ and $\mathrm{Mg}++)$ and the di-sodium salt of EDTA extracts the metal ions from the dye-metal ion complex as colourless chelate complexes leaving a blue coloured aqueous solution of the dye. Finally, monthly mean values were then calculated for all the above mentioned physico-chemical parameters.

\section{Study of biometric indices}

Biometric parameters like total weight (T.W.), total length (T.L.), standard length (S.L.), forkal length (F.L.) and Weight of gonad were measured for each of the collected specimen. T.L. measured from snout to the base of caudal fin rays; S.L. from the tip of snout to the base of caudal fin; F.L. from the tip of snout to the forked point of the caudal fin to the nearest $1 \mathrm{~mm}$ using a measuring tape and graduated ruler. T.W. of the samples was measured using digital balance to the nearest $0.1 \mathrm{~g}$. All these parameters were recorded on a data collection sheet.

Inorder to measure the gonad weight the collected fishes were dissected with the help of a pair of sharp scissors through their abdominal part. The gonads were extracted and the weight of each gonad was noted with the help of digital weighing balance to the nearest $0.1 \mathrm{~g}$.

\section{Fecundity}

Inorder to study the fecundity, ovaries were preserved in Gilson's fluid for over ninety (90) days to loosen the tissue ssurrounding the eggs. The eggs were then gently washed with distilled water until they became disentangled from the ovarian tissues. The eggs were then spread over blotting paper to remove excess moisture. Clamped eggs were gently separated and then airdried for 24 hours at room temperature. The fecundity was calculated by using the following formula: Fecundity $(\mathrm{F})=$ Total weight of eggs in the ovary * Count in $1 \mathrm{~g}$ of egg mass

\section{Gonadosomatic index (GSI)}

The gonadosomatic index (GSI) was calculated for each fish using the following formula: GSI=Weight of the gonad / Total weight of the fish * 100

\section{Results}

Altogether 56 male and 69 female fishes were examined from December 2014 till the end of October 2015. The male to female ratio was 1:1.2.

The gonado-somatic index ranged from $0.084 \%$ (in a fish of standard length $16.5 \mathrm{~cm}$ and total weight $95 \mathrm{~g}$ ) to $16.47 \%$ (in a fish of standard length $25 \mathrm{~cm}$ and total weight $340 \mathrm{~g}$ ) for female fish and $0.086 \%$ (in a fish of standard length $11.9 \mathrm{~cm}$ and $35 \mathrm{~g}$ ) to $5.81 \%$ (in a fish of standard length $24 \mathrm{~cm}$ and $240 \mathrm{~g}$ ). The highest mean GSI $9.037 \%$ was recorded in July for female fishes and the highest $2.838 \%$ was recorded in September for male fishes.

Pearson correlation coefficients were computed in order to understand the association and relationship of different biometric indices among each other and with different physical and chemical parameters.

The total weight and total length of the fishes had strong positive correlation ( $\mathrm{r}=0.93$ for female fishes and $\mathrm{r}=0.82$ for male fishes). Also, the correlation between the weight of gonad and GSI was positively correlated but, that for the female fishes was higher $(r=0.84)$ than that for the male fishes $(\mathrm{r}=0.37)$. Atmospheric temperature ranged from $27^{\circ} \mathrm{C}$ to $34^{\circ} \mathrm{C}$ and water temperature ranged from $16.25^{\circ} \mathrm{C}$ to $25^{\circ} \mathrm{C}$ (Fig. 2, Table 1) 


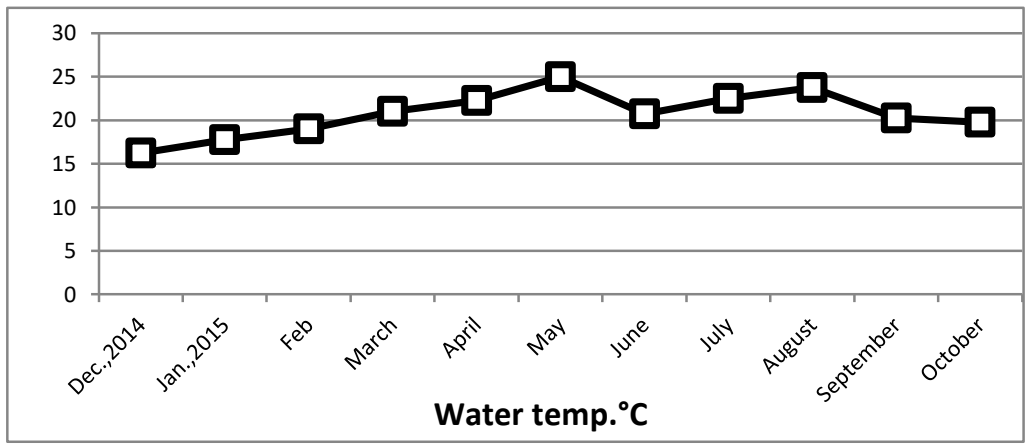

Figure 2. Monthly mean water temperature

Total body weight of female fish and water temperature showed strong positive correlation $(\mathrm{r}=$ 0.79). Monthly mean GSI of female fish and water temperature had moderate strong correlation with each other $(r=0.60)$. Similarly, total body weight of male fish and water temperature showed moderate strong positive correlation $(\mathrm{r}=0.48)$. Monthly mean GSI of male fish and water temperature showed strong positive correlation with each other $(r=0.76)$. During the study period, $\mathrm{pH}$ of water samples varied from 6.31 to 7.72 (Fig. 3, Table 1).

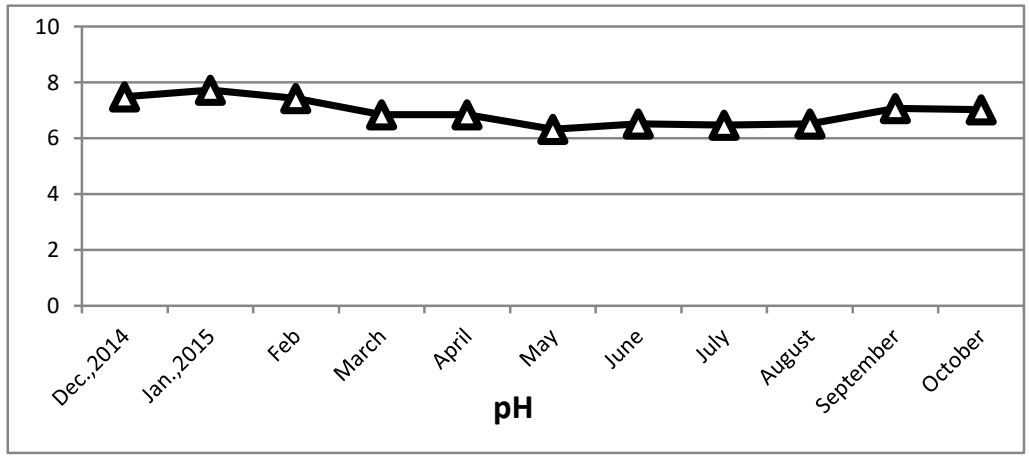

Figure 3. Monthly mean $\mathrm{pH}$

Total body weight and water $\mathrm{pH}$ showed strong negative correlation $(\mathrm{r}=-0.9$ for female fish and $\mathrm{r}=-0.74$ for male fish). Similarly, GSI and $\mathrm{pH}$ showed negative correlation with each other ( $r=-0.47$ for female fish and $r=-0.68$ for male fish). Dissolved oxygen (DO) ranged from $8.35 \mathrm{mg} / \mathrm{L}$ to $10.6 \mathrm{mg} / \mathrm{L}$ (Fig. 4, Table 1 ).

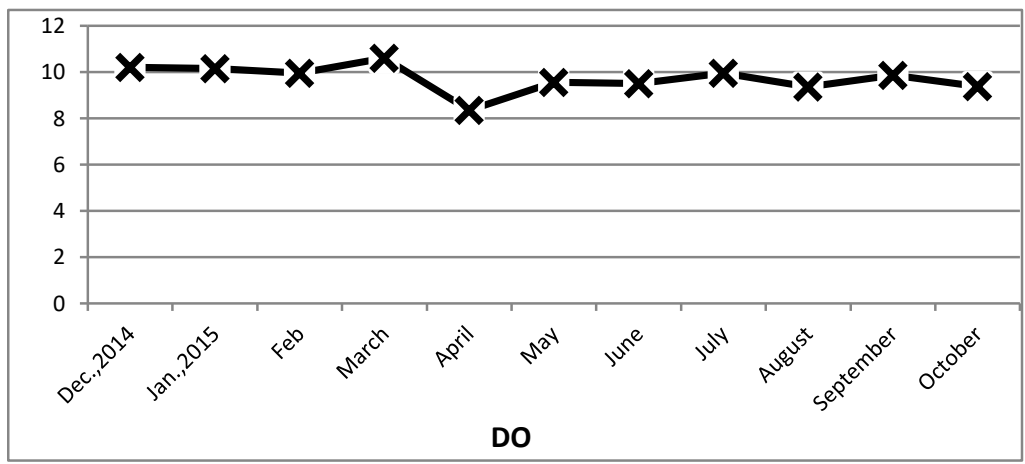

Figure 4. Monthly mean Dissolved Oxygen (DO) 
Total body weight and DO showed negative correlations with each other $(r=-0.422$ for female fish and $r=-0.20$ for male fish). Similarly, GSI and DO showed negative correlations with each other $(r=-0.23$ for female fish and $r=-0.63$ for male fish). During the study period Total Hardness ranged from $22.25 \mathrm{mg} / \mathrm{L}$ to $48 \mathrm{mg} / \mathrm{L}$ (Fig. 5, Table 1)

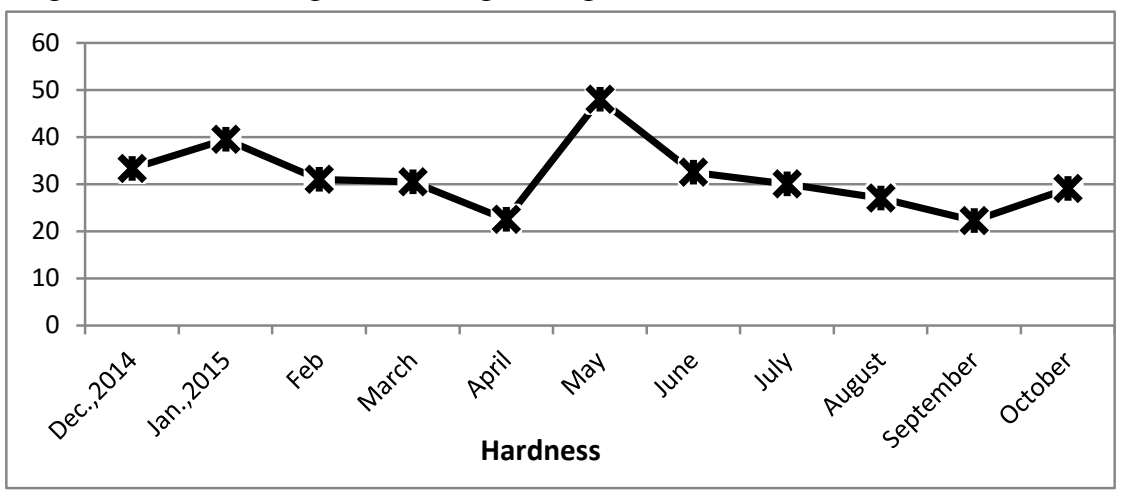

Figure 5. Monthly mean Total Hardness of water

Total alkalinity ranged from $13.25 \mathrm{mg} / \mathrm{L}$ to $18.13 \mathrm{mg} / \mathrm{L}$ (Fig.6, Table 1).

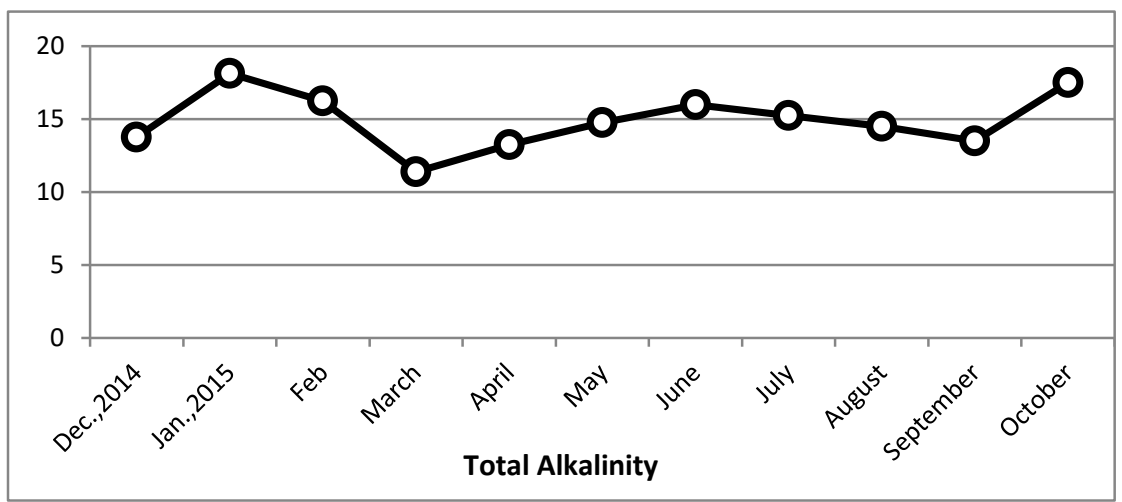

Figure 6. Monthly mean total alkalinity

During the study period, the free Carbondioxide (Free CO2) ranged from $1.5 \mathrm{mg} / \mathrm{L}$ to $4.35 \mathrm{mg} / \mathrm{L}$ (Fig. 7, Table 1)

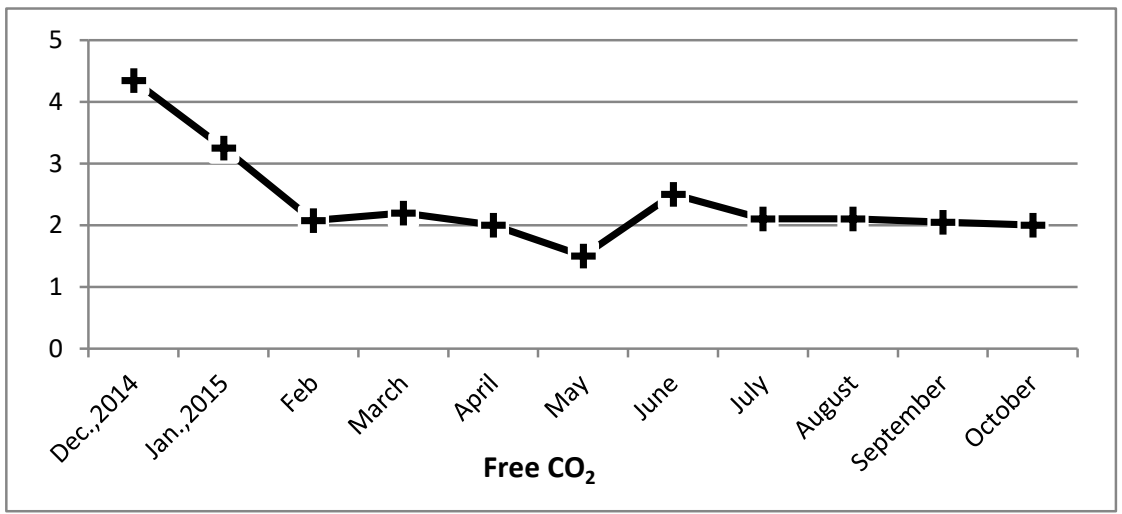

Figure 7. Monthly mean Free CO2 
Pearson correlation matrix was calculated by using SYSTAT-12 software for different physicochemical parameters (Temperature, pH, Dissolved Oxygen, Free CO2, Alkalinity, Hardness) (Table. 2).

Atmospheric temperature was found to have strong positive correlation with water temperature $(\mathrm{r}=0.9)$, strong negative correlations with $\mathrm{DO}(\mathrm{r}=-0.74)$ and free $\mathrm{CO}_{2}(\mathrm{r}=-0.73)$. It had very weak correlations with other parameters like $\mathrm{pH}$, total hardness, total alkalinity.

Water temperature was found to have weak negative correlation with $\mathrm{pH}(\mathrm{r}=-0.321)$ and moderately weak correlation with DO $(\mathrm{r}=-0.54)$. It had weak positive correlation with total hardness $(r=0.24)$. It had very weak positive correlation with total alkalinity $(r=0.08)$. It had strong negative correlation with free $\mathrm{CO}_{2}(\mathrm{r}=-0.91)$.

$\mathrm{pH}$ had weak positive correlation with DO $(\mathrm{r}=0.37)$ and moderate positive correlation with total hardness $(\mathrm{r}=0.55)$ and strong positive correlation with total alkalinity $(\mathrm{r}=0.76)$. It had weak positive correlation with free $\mathrm{CO}_{2}(\mathrm{r}=0.49)$.

Dissolved oxygen (DO) was found to have weak positive correlation with total hardness $(\mathrm{r}=$ $0.31)$, total alkalinity $(\mathrm{r}=0.36)$ and free $\mathrm{CO}_{2}(\mathrm{r}=0.37)$.

Total hardness had strong positive correlation with total alkalinity $(r=0.93)$ but very weak negative correlation with free $\mathrm{CO}_{2}(\mathrm{r}=-0.08)$.

Total alkalinity had very weak negative correlation with free $\mathrm{CO}_{2}(\mathrm{r}=-0.06)$.

Absolute fecundity of 11 gravid stage female individuals of $N$. hexagonolepis ranged from 3600 for fish of total length (TL-cm) $32.4 \mathrm{~cm}$, total weight (TW-g) $410 \mathrm{~g}$ and gonad weight (GW-g) $35 \mathrm{~g}$ to 11424 for fish of total length (TL-cm) $37 \mathrm{~cm}$, total weight (TW-g) $710 \mathrm{~g}$ and gonad weight (GW-g) $102 \mathrm{~g}$.

Fecundity had strong positive correlation with gonad weight $(\mathrm{r}=0.98)$, total weight $(\mathrm{r}=0.9)$ and total length $(r=0.88)$.

Table 1. Physico-Chemical parameters (Monthly mean)

\begin{tabular}{lccccccc}
\hline Month & $\begin{array}{c}\text { Atm } \\
\text { Temp. } \\
{ }^{\circ} \mathbf{C}\end{array}$ & $\begin{array}{c}\text { Water } \\
\text { Temp. } \\
{ }^{\circ} \mathbf{C}\end{array}$ & $\mathbf{p H}$ & $\begin{array}{c}\text { DO } \\
\mathbf{m g} / \mathbf{L}\end{array}$ & $\begin{array}{c}\text { Total } \\
\text { Hardn } \\
\text { ess }\end{array}$ & $\begin{array}{c}\text { Total } \\
\text { Alkali } \\
\mathbf{m g} / \mathbf{L}\end{array}$ & $\begin{array}{c}\text { Free } \\
\mathrm{CO}_{2} \\
\mathbf{m g} / \mathbf{L}\end{array}$ \\
\hline Dec.,2014 & 27 & 16.25 & 7.485 & 10.2 & 33.25 & 13.75 & 4.35 \\
January,2015 & 27.5 & 17.85 & 7.72 & 10.15 & 39.5 & 18.125 & 3.25 \\
February & 28 & 19 & 7.4225 & 9.95 & 31 & 16.25 & 2.075 \\
March & 28.5 & 21 & 6.8425 & 10.6 & 30.5 & 11.375 & 2.2 \\
April & 33.5 & 22.25 & 6.83 & 8.35 & 22.5 & 13.25 & 2 \\
May & 34 & 25 & 6.31 & 9.55 & 48 & 14.75 & 1.5 \\
June & 32.5 & 20.75 & 6.5125 & 9.5 & 32.5 & 16 & 2.5 \\
July & 32.75 & 22.5 & 6.465 & 9.95 & 30 & 15.25 & 2.1 \\
August & 31.75 & 23.75 & 6.5025 & 9.35 & 27 & 14.5 & 2.1 \\
September & 28.75 & 20.25 & 7.0625 & 9.85 & 22.25 & 13.5 & 2.05 \\
October & 28.5 & 19.75 & 7.0125 & 9.375 & 29 & 17.5 & 2 \\
\hline
\end{tabular}


Table 2. Correlation matrix of Physico-chemical parameters

\begin{tabular}{lccccccc}
\hline Parameters & Atm. temp. & Water temp. & pH & DO & TH & TA & Free CO2 \\
\hline Atm. temp. & 1.00 & & & & & & \\
Water temp. & 0.90 & 1.00 & & & & & \\
pH & -0.42 & -0.312 & 1.00 & & & & \\
DO & -0.74 & -0.54 & 0.37 & 1.00 & & & \\
TH & 0.1 & 0.24 & 0.55 & 0.31 & 1.00 & & \\
TA & -0.05 & 0.08 & 0.72 & 0.36 & 0.93 & 1.00 & \\
Free CO2 & -0.73 & -0.91 & 0.49 & 0.37 & -0.08 & -0.06 & 1.00 \\
\hline \multicolumn{7}{c}{ Bold values indicate significant if $\mathrm{r}> \pm 0.65 ; \mathrm{p}<0.01$} \\
\end{tabular}

\section{Discussion}

The male to female ratio was significantly different $(\mathrm{P}<0.05)$ from the expected ratio 1:1. More females were observed in the population which was similar to the findings in the Indrasarobar reservoir but different from the Tadi river (Swar \& Craig, 1994). Mahapatra and Vinod (2011) reported the sex ratio to be in the favor of males in ICAR Fish farm at Barapani, Meghalaya. However the sex ratio was not significantly different as in other studies. The imbalance in the sex ratio was probably related to the differences in age-related mortality and spawning migrations. The sampling sites were the spawning areas and the females stayed longer in those areas as compared to the males.

High Gonadosomatic index recorded in the months of June, July and August suggest the possible spawning period of $N$. hexagonolepis which coincided with the rainy season. High gonadosomatic indices were also observed in other studies. Mahapatra and Vinod (2011) reported that the fishes were found to mature from May onward and gravid fishes were available in rivers from July to September. GSI in ripe female reported by them (GSI=16.19) was similar to the present study (GSI=16.47). According to Khaironizam and Ismail (2012), the peak values of GSI of $N$. soroides were observed in the months of December and April which were in sharp contrast to the present study. In the present study the females at the mature stage yielded much higher GSI values as compared to males and this suggests that the gonads of females in the same maturity stage are heavier as compared to those of males.

Fecundity of $N$. hexagonolepis in this study ranged from 3600 to 11424 . This is similar to the range observed by Swar and Craig (2008) on the fecundity of $N$. hexagonolepis in Tadi river. The range of fecundity of the fish in this study was similar to the range obtained through artificial fecundation as reported by Mahapatra and Vinod (2011). But this was higher as compared to the fecundity of $N$. soroides which ranges from 803 to 6218 per fish as reported by Khaironizam and Ismail (2012). Fecundity study of this fish revealed that $N$. hexagonolepis is not so high fecund fish as compared to other high fecund fish with millions of eggs. Although the fecundity of this fish was significantly correlated with total length, total body weight and ovary weight, the regression coefficient from the fecundity and these relationships show that fecundity is more related to ovary weight than to body weight and body length. This result suggests that the increase in the number of eggs results in the increase of ovary weight. Fecundity was more related with total weight as compared to total length and the result suggests that the body weight is more related to length of the body. Also, there is a linear relationship between fecundity and total length which suggests that larger mature fish would be expected to carry more eggs in the ovary. 


\section{Acknowledgements}

The authors are thankful to Dr. Bharat Raj Subba for painstaking help and encouragement during the field study and lab work.

\section{References}

Ferro, W. \& Badagami, P.R. 1980. On the biology of the commercially important fish species of Pokhara Valley (Nepal). J. Inst. Sc. T.U. Kathmandu 3(1):237-250.

IUCN, 2012. IUCN Red List of Threatened Species. Version 2012.1. IUCN 2012. IUCN Red List of Threatened Species. Downloaded in Jan 2014.

Khaironizam, M.Z. \& M.Z. Ismail 2012. Spawning period and fecundity of Neolissochilus soroides (Duncker, 1904) (Pisces, Teleostei, Cyprinidae) from a small Malaysian stream. Turkish Journal of Zoology. pp 65-72.

Mahapatra, B.K. \& K. Vinod 2011. Reproductive biology and artificial propagation of chocolate mahaseer Neolissocheilus hexagonolepis (Mc Clelland) in Meghalaya, India. Indian J. Fish., 58(2): $35-40$

Mahapatra,B.K., K. Vinod \& B.K.Mandal 2004. Studies on chocolate mahseer, Neolissochilus hexagonolepis (Mc Clelland) fishery and the cause of its decline in Umiam reservoir,Meghalaya. J.Natcon., 16(1):199-205

Marwein, B. 2000. Fish biodiversity of north east India. In: Ponniah, A.G. and Sarkar, U.K. (Eds.) life history traits of Neolissochilus hexagonolepis (Mc Clelland), NATP Publ.2, NBFGR,Lucknow,p.131-133

Menon, A.G.K., 1999. Check list - fresh water fishes of India. Rec. Zool. Surv. India, Misc. Publ., Occas. Pap. No.175, 366 p.

Mohammad, A.A.\& Mohammad, A. 2012. Reproductive biology of Gangetic hairfin anchovy Setipinna phasa from the Halda River. $5^{\text {th }}$ Fisheries Conference \& Research Fair, Bangladesh.

Rai, A.K. \& D.B. Swar, 1989. Katle (Acrossocheilus hexagonolepis), a coldwater cyprinid of Nepal. FAO Fish. Rept. (405, Suppl.): 95-99.

Shrestha, T.K. 2003. Coservation and Management of Fishes in the large Himalayan Rivers of Nepal. International Symposium on the Management of Large Rivers for Fisheries: Sustaining Livelihoods and Biodiversity in the New Millenium, 11-14 February 2003. Phnom Penh. Nepal.

Swar, D. 1994. A study on the ecology of Katle, Neolissocheilus hexagonolepis (Mc Clelland) in a Nepalese reservoir and river. PhD thesis, The University of Manitoba, Winnipeg, Manitoba.216p.

Swar, D.B., \& Craig, J.F. 2008. Katle (Neolissocheilus hexagonolepis Mc Clelland): Reproduction in the Indrasarovar reservoir and the Tadi river, Nepal. In: Cold Water Fisheries in the Trans-Himalayan Countries (Eds. T. Petr and S.B. Swar). FAO Technical Paper No. 431, Rome, pp. 293-301. 